\title{
Appearance of a population of the mangrove rail Rallus longirostris Boddaert, 1783 (Rallidae) in salt marshes invaded by the exotic tanner grass Urochloa arrecta (Poaceae) and its disappearance after plant management
}

\section{Marcos R. Bornschein}

UNESP Campus Experimental do Litoral Paulista: Universidade Estadual Paulista Julio de Mesquita Filho - Campus Experimental do Litoral Paulista

\section{Bianca L. Melchiori}

UNESP Campus Experimental do Litoral Paulista: Universidade Estadual Paulista Julio de Mesquita Filho - Campus Experimental do Litoral Paulista

\section{Larissa Teixeira}

UNESP Campus Experimental do Litoral Paulista: Universidade Estadual Paulista Julio de Mesquita Filho - Campus Experimental do Litoral Paulista

Bianca L. Reinert

In memorian

Giovanna Sandretti-Silva ( $\sim$ giovanna.sandretti@unesp.br)

Universidade Estadual Paulista: Universidade Estadual Paulista Julio de Mesquita Filho

\section{Research Article}

Keywords: competition, ecological trap, estuary, nesting site, Pardirallus nigricans, restoration

Posted Date: January 28th, 2022

DOI: https://doi.org/10.21203/rs.3.rs-1281152/v1

License: (c) (1) This work is licensed under a Creative Commons Attribution 4.0 International License. Read Full License 


\section{Abstract}

Biological invasions cause species extinction, but also provide benefits. Wetlands, such as salt marshes, include little known but important ecosystems that are sometimes severely invaded by exotic plants. Salt marshes in eastern South America are increasingly impacted by the invasion of the African grass Urochloa arrecta. This study investigated the appearance of a population of the mangrove rail Rallus longirostris in areas dominated by $U$. arrecta and its disappearance with the eradication of this plant. We monitored four areas (38.63 ha) in Guaratuba Bay estuary in southern Brazil, from 2006-2022, two of which contained four patches of $U$. arrecta as the dominant species. In 2012, we started to eradicate $U$. arrecta with mechanical management, and in 2020, it was eradicated locally. In 2007, we recorded $R$. longirostris for the first time in a patch of $U$. arrecta, and in subsequent years, we saw the bird in two other patches of the exotic plant. Rallus longirostris was no longer recorded when $U$. arrecta was eradicated. We hypothesized that $R$. longirostris used patches of $U$. arrecta as vacant nesting niches due to a lack of competition with Pardirallus nigricans -the most common bird in the estuary-which does not frequent patches of $U$. arrecta. The invasion of $U$. arrecta can locally increase the populations of $R$. longirostris. Although this bird is at risk of extinction in parts of its geographic distribution, we encourage the management of $U$. arrecta because of its impact on salt marshes.

\section{Introduction}

The introduction of alien species has intensified with globalization in recent decades (Meyerson and Mooney 2007). Exotic species are defined as species that are not native to an ecosystem and that cause or are likely to cause economic, environmental, and/or human health damage (Catling 2005). They can change the composition of ecosystems rapidly and profoundly (Hobbs et al. 2009) and, through their direct and indirect effects, contribute substantially to species extinction (Vitousek et al. 1997; Bellard et al. 2006). Consequently, biological invasions are considered the second most common cause of biodiversity loss (Simberloff 2007). However, the effects of invasive species are not all negative, and the "native good, alien bad" dichotomy has been questioned (Goodenough 2010). Exotic species can benefit native species through habitat modification, trophic subsidy, pollination, competitive release, and predator release mechanisms (Overton et al. 2014). Understanding and studying the responses of native species to invasive alien species is essential for understanding impacts and deciding conservation actions (Schlaeper et al. 2002).

Wetlands comprise ecosystems that are greatly disturbed by biological invasions (Levin et al. 2006; Reinert et al. 2007; Norbdy et al. 2009; Cuassolo et al. 2012). These environments are extremely important, and despite covering only $6 \%$ of the Earth's surface, they host $24 \%$ of the most invasive species on the planet (Zedler and Kercher 2004). Salt marshes are a type of wetland and possibly the most important and least understood of the world's major ecosystems (Gedan et al. 2011). These are dynamic coastal areas (Watson and Byrne 2009; Gedan et al. 2011) that host salt-tolerant plant species (Doody 2001). They are regularly flooded by tides, have rapid sediment accumulation, and include transitions to non-tidal vegetation in the absence of human interference (Doody 2001). They occur in 
temperate areas across the globe, are more extensive in the northern hemisphere, and have seagrass Spartina spp. as the most common plant species (Doody 2001). Recently, some marshes on parts of the South American Atlantic coast have been recognized as salt marshes-specifically, subtropical salt marshes (Bornschein et al. 2017). They are characterized by the dominance of the crinum lily Crinum americanum L. and the California bulrush Schoenoplectus californicus (C. A. Mey.) Soják; therefore, the presence of smooth cordgrass Spartina alterniflora Loisel is rare (Bornschein et al. 2017). Subtropical salt marshes occur in association with mangroves, distributed in Brazil to a small extent from the estuaries of the central-south coast of São Paulo to the north coast of Santa Catarina (Bornschein et al. 2017).

Tanner grass Urochloa arrecta (Hack. ex T. Durand \& Schinz) Morrone \& Zuloaga invasion and domination of South American salt marshes is the greatest threat to the conservation of endemic birds in southern Brazil and was described only in 1995 regarding the marsh antwren Formicivora acutirostris (Reinert et al. 2007). Environments completely invaded by exotic grass are no longer occupied by this bird, which is why the impact is considered an area suppressor (Reinert et al. 2007). In contrast, marshes in California, USA, were invaded by a hybrid species of Spartina that benefited populations of the threatened Ridgway's rail Rallus obsoletus (taxonomy according to Maley and Brumfield [2013]). The hybrid form increases the survival rate of individuals of this bird by providing refuge against predators during extreme tides that inundate native vegetation, particularly during winter when native vegetation enters senescence (Overton et al. 2014). Hybrid plant management programs reduced the survival rate of $R$. obsoletus, and the plans for its conservation suggested offering refuges against high tides resulting from rises in sea level (Overton et al. 2014).

From 2006-2022, salt marshes in southern Brazil have been studied as part of a long-term project aiming to monitor and conserve $F$. acutirostris-an endangered (EN) species at risk of extinction in Brazil (Ordinance \#444 of the Brazilian Ministério do Meio Ambientes, December 17, 2014). In 2012, F. acutirostris conservation efforts encompassed a challenging program that aimed to eradicate $U$. arrecta (Bornschein 2013), which was impacting a local population of the mangrove rail Rallus longirostris Boddaert, 1783. The Rallus longirostris is generally restricted to mangroves (Vieira 2015) and distributed across small portions of the Pacific coastal region, Central America, and northern South America, and along a vast stretch of the Atlantic coast in South America (Maley et al. 2016). A significant extent of the species' geographic distribution occurs along the Atlantic coast of Brazil-a country in which it was considered at risk of extinction (Vieira 2015). In this article, we report on the appearance and distributional expansion of $R$. longirostris on subtropical salt marshes invaded by $U$. arrecta and its disappearance after the eradication of this plant. We also discuss the possible causes of this appearance and disappearance.

\section{Methods}

\section{Study Species}


The target species was the mangrove rail Rallus longirostris, which is considered a separate species from the North American R. obsoletus and the clapper rail R. crepitans (Maley and Brumfield 2013; Chesser et al. 2014).

\section{Study Areas and Field Time}

We worked in the Guaratuba Bay estuary, RAMSAR Site Guaratuba, in the municipality of Guaratuba, on the southern coast of Paraná, in southern Brazil. Specifically, we studied four areas: Jundiaquara Island

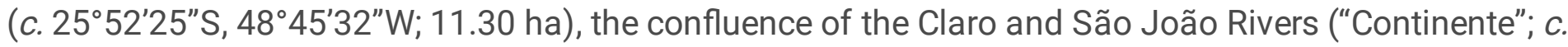

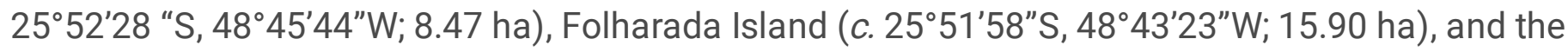

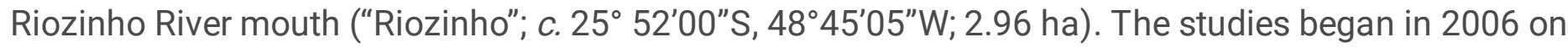
Jundiaquara Island and Riozinho, in 2007 at Continente, and in 2009 on Folharada Island. In all locations, we carried out the work until January 2022. Between January 2006 and May 2008, we worked in the areas daily from September to February and for 6-8 days per month for the rest of the year. From 2009 onward, we worked in the areas for 3-8 days per month, every month. We did not work in the areas for six straight months in 2020 due to the COVID-19 pandemic (March-August). Fieldwork was carried out by 2-7 people (usually three). We accessed the places by boat. On each fieldwork day, we worked from dawn until 12 a.m. or 1 p.m., and for a further $2-3.5 \mathrm{~h}$ in the afternoon, before dusk. We specifically studied $F$. acutirostris in the sampling effort (see Bornschein et al. 2015), but in all the areas described, we noted the presence, abundance, and nesting aspects of the other local birds.

\section{Studied Environments}

The study areas are estuaries flooded daily by high tides and classified as estuarine marshes (Doody 2001: 65), tidal marshes (Reinert et al. 2007), or subtropical salt marshes (Bornschein et al. 2017). According to the criteria for the classification of Brazilian vegetation proposed by the RADAMBRASIL Project (Veloso et al. 1991), marshes are pioneer formations with fluviomarine influences. The following herbaceous species dominate: $C$. americanum (Amaryllidaceae), S. californicus, Fuirena robusta Kunth, Cladium mariscus (L.) Pohl (Cyperaceae), Acrostichum danaeifolium Langsd. \& Fisch. (Pteridaceae), and Stephostachys mertensii (Roth) Zuloaga \& Morrone (Poaceae) (Reinert et al. 2007). The herbaceous southern cattail Typha domingensis Pers. also occurs locally (Typhaceae; Fig. 1A). Trees are present, such as Calophyllum brasiliense Cambess. (Clusiaceae), Annona glabra L. (Annonaceae), and Laguncularia racemosa (L.) C.F. Gaertn. (Combretaceae) (Reinert et al. 2007). In these areas, there is a mixed semi-diurnal tide (Lee and Chang 2019), with two high tides and two low tides of different amplitudes on all lunar days.

\section{Local Impact and Management of Urochloa arrecta}

In the studied areas, there were patches of the alien African species tanner grass Urochloa arrecta (or Brachiaria subquadrippara) as the dominant species (Fig. 1B). Native species co-occur with alien species but at low frequencies. Urochloa arrecta has become a dominant species due to the accumulation of stolons that shade and crush native vegetation, causing the death of native plants (Fig. 2B; Reinert et al. 
[2007]). A subtropical salt marsh vegetation structure, with space on the ground and in the vertical column of vegetation for the movement of birds, no longer exists in areas dominated by this alien species (Fig. 2A; Reinert et al. [2007]). Urochloa arrecta also advances over the water as floating banks of vegetation that are sometimes ripped out by floods and transferred to other areas previously free of its presence (Reinert et al. 2007).

Urochloa arrecta was mechanically managed until its complete local eradication, without the use of herbicides, by clear-cutting vegetation with brush cutters and stacking plant biomass (Bornschein 2013). The stacked biomass was contained with stakes so that the high tides could not move it (Fig. 3). We obtained management permissions from the Instituto Ambiental do Paraná (\#357/11) and Instituto Água e Terra (\#12.20).

These piles contained biomass mixed up to six times. Biomass from the interior of the pile, already dead, was moved to the edge of the pile, and that from the edge drawn inward toward the interior (Bornschein 2013). Up to six inspections were carried out in the managed areas to remove rooted and sprouted fragments of the alien species, which were pulled out by hand and placed in piles (Bornschein 2013). Urochloa arrecta does not form seed banks locally, and within 10 months of the start of management, the native vegetation covered the land again, free from the presence of alien species (Bornschein 2013). We delimited and measured polygons of areas invaded by $U$. arrecta and managed them using the Google Earth Pro program (7.3.3.7786) and the advances and reductions in invaded areas shown in the program's historical orbital images.

\section{Results}

We recorded Rallus longirostris for the first time in 2007, observing and recording two individuals vocalizing in duet in a patch dominated by $U$. arrecta in Riozinho (Patch 1; Table 1; Fig. 4). In 2010, this patch of $U$. arrecta covered 1.23 ha (Table 1). It was $43 \mathrm{~m}$ away from Patch 2 and $80 \mathrm{~m}$ away from Patch 3 of $U$. arrecta, with 0.22 ha and 0.17 ha, respectively (Table 1 ; Fig. 4B), in which we did not record $R$. longirostris. This bird became regular in Patch 1 of $U$. arrecta, where it also nested. We still observed the bird in the vicinity of Patch 1, on subtropical salt marshes free of exotic grass. We even observed $R$. longirostris on almost every field day during 2008-2012 in Patch 1, when the tide was low, feeding on small shrimp thrown onto the riverbanks by boat waves. Two photographs on the WikiAves website (https://www.wikiaves.com.br/) document the presence of the bird in the vicinity of Patch 1 of $U$. arrecta, one from 2007 and another from 2012 (WA280252 and WA832943). In 2010, we recorded R. longirostris at the Continente in a 0.10-ha patch dominated by $U$. arrecta (Patch 4; Table 1; Fig. 4B). We saw only one couple and listened to them regularly. We observed three nests with eggs in subsequent years on a mass of $U$. arrecta stolons. We also observed lone individuals or couples of $R$. longirostris on subtropical salt marshes up to $441 \mathrm{~m}$ distant from patches of $U$. arrecta (in this case, on Jundiaquara Island; 22'14"S, $\left.48^{\circ} 45^{\prime} 32^{\prime \prime} \mathrm{W}\right)$. 
Table 1

Sizes of Urochloa arrecta (Hack. ex T. Durand \& Schinz) Morrone \& Zuloaga patches on subtropical salt marshes before and after management in Guaratuba Bay, Paraná, southern Brazil. The years in which Rallus longirostris Boddaert, 1783 was recorded by patch are highlighted in bold. We also indicate the sizes of the patches of $U$. arrecta in 2003 as a reference value prior to the beginning of the fieldwork (in 2006).

\begin{tabular}{|c|c|c|c|c|}
\hline \multirow[t]{2}{*}{ Year } & \multicolumn{4}{|c|}{ Patches dominated by Urochloa arrecta (in bold the ones with records of Rallus longirostris) } \\
\hline & $\# 1^{\mathrm{a}}$ & $\# 2^{\mathrm{a}}$ & $\# 3^{\mathrm{a}}$ & $\# 4^{\mathrm{b}}$ \\
\hline 2003 & 0.38 ha & 0.00 ha & 0.11 ha & 0.01 ha \\
\hline 2006 & ? ha & ? ha & ? ha & ? ha \\
\hline 2007 & ? ha & ? ha & ? ha & ? ha \\
\hline 2008 & ? ha & ? ha & ? ha & ? ha \\
\hline 2009 & ? ha & ? ha & ? ha & ? ha \\
\hline 2010 & $1.23 \mathrm{ha}$ & 0.22 ha & 0.17 ha & 0.1 ha \\
\hline 2011 & ? ha & ? ha & ? ha & ? ha \\
\hline 2012 & 1.00 ha & 0.32 ha & 0.18 ha & 0.13 \\
\hline 2013 & ? ha & ? ha & ? ha & ? ha \\
\hline 2014 & 0.59 ha & 0.45 ha & $0.23 \mathrm{ha}$ & 0.15 ha \\
\hline 2015 & ? ha & ? ha & ? ha & ? ha \\
\hline 2016 & 0.01 ha & 0.57 ha & 0.00 ha & 0.16 ha \\
\hline 2017 & 0.00 ha & 0.40 ha & 0.00 ha & 0.01 ha \\
\hline 2018 & 0.01 ha & 0.28 ha & 0.00 ha & 0.01 ha \\
\hline 2019 & 0.02 ha & 0.30 ha & 0.00 ha & 0.00 ha \\
\hline 2020 & 0.25 ha & 0.46 ha & 0.00 ha & 0.00 ha \\
\hline 2021 & 0.00 ha & 0.00 ha & 0.00 ha & 0.00 ha \\
\hline \multicolumn{5}{|c|}{ a Riozinho } \\
\hline b Cont & ente & & & \\
\hline
\end{tabular}

In 2012, we started managing $U$. arrecta in Patch 1. In 2015, we still recorded $R$. longirostris in this patch (Table 1), and on that occasion, we observed $R$. longirostris feeding on Leptuca mordax chased away by the management brush cutters. The bird was nesting on top of a biomass pile of managed vegetation (but the eggs were preyed upon). In 2016, Patch 1 of $U$. arrecta was practically eliminated, and since then, $R$. longirostris has not been recorded at this location. Also in 2016, we started to record $R$. longirostris in a (then) 0.57-ha Patch 2 of $U$. arrecta (Table 1), but only a few times a year, suggesting either a tiny 
population or irregular occurrence. In 2021, we eradicated $U$. arrecta from Patch 2 , and since the beginning of 2021, we have not recorded any $R$. longirostris in it (Table 1). We started managing the (then) 0.16-ha Patch 4 of $U$. arrecta in 2016 (Table 1). In 2017, we practically eradicated this patch of $U$. arrecta, and we no longer recorded $R$. longirostris at the site (Table 1 ).

In Patch 3 of $U$. arrecta, which reached 0.23 ha, we recorded no R. longirostris (Table 1). In 2015, this patch of $U$. arrecta was eradicated. On Folharada Island, where $U$. arrecta was absent, we also recorded no $R$. longirostris.

\section{Discussion}

This long-term study allowed us to verify the 1 ) appearance of a population of $R$. longirostris occupying and nesting in patches dominated by the exotic $U$. arrecta; 2 ) increase in its geographic distribution, with the occupation of other patches dominated by this plant; and 3) disappearance after the eradication of the plant. This is a further case of a native species benefiting from an alien species invasion (see Maley and Brumfield 2013) and evidence of a preference for an altered over a natural environment for nesting. This suggests that i) the subtropical salt marsh structurally impedes the nesting of $R$. longirostris or that ii) there is an ecological impediment to nesting in this environment not invaded by $U$. arrecta.

Regarding Hypothesis " $\mathrm{i}$ ", the most abundant bird at the study sites was the blackish rail Pardirallus nigricans, which is similar in size to $R$. longirostris (Dunning 2008) and nests in the subtropical salt marshes (MRB per. obs.). Locally, these two birds build nests as baskets made from fragments of native herbaceous plants of similar size, supported over the herbaceous vegetation ( $\mathrm{n}=4$ nests of $R$. longirostris, $\mathrm{n}=\mathrm{c}$. 150 nests of $P$. nigricans). Thus, subtropical salt marshes are environments in which herbaceous plants support the construction of relatively large bird nests. This, however, leads to the possibility that there could be disputes over reproductive sites between these birds on subtropical salt marshes (Hypothesis ii), with P. nigricans dominating over $R$. longirostris. We suggest that $R$. longirostris could have occupied the patches dominated by $U$. arrecta as vacant nesting niches, eliminating disputes with P. nigricans.

Pardirallus nigricans does not seem to use areas dominated by exotic $U$. arrecta, possibly due to the high density of vegetation (Fig. 2B), which limits its movements and access to food (MRB per. obs.). This bird also apparently does not nest in patches invaded by exotic species, perhaps due to the reduced structural complexity of the vegetation. Birds such as $R$. obsoletus generally prefer more complex environments for nest building (Rush et al. 2010), whereas patches dominated by $U$. arrecta have a simplified vegetation structure (Reinert et al. 2007) and appear to be undesirable for the nesting of other subtropical salt marsh birds (MRB per. obs.). The only apparent benefit of nesting in patches dominated by $U$. arrecta is the buoyancy of the biomass under high tide conditions, which could potentially reduce reproductive losses from flooding-an impact that is quite significant for wetland birds (Marshall and Reinert 1990; Shriver 2002; Greenberg et al. 2006; Reinert 2006; Norbdy et al. 2009). In the study region, high tides flood the nests of at least $F$. acutirostris (Reinert et al. 2012), the least bittern Ixobrychus exilis, $P$. nigricans, the 
wren-like rushbird Phleocryptes melanops, the yellow-chinned spinetail Certhiaxis cinnamomeus, the many-colored rush tyrant Tachuris rubrigastra, and the Brazilian tanager Ramphocelus bresilia (MRB per. obs.).

The principle of equal opportunity (MacArthur 1972), which predicts that the occupation of environments by species depends on the relationship between the resources of that habitat and the pressure to use them, meaning that individuals up to a certain point prefer less competitive environments, could be a factor in the choice of use of the environment by $R$. longirostris and $P$. nigricans and their consequent nesting in patches of $U$. arrecta by the former. The occupation of environments depends on competition (Cody 1985), and few species can occupy resource-poor habitats, such as patches of $U$. arrecta with impoverished flora and a simplified vegetation structure, which leads to reduced competition (Cody 1985). Rallus longirostris could have benefited from occupation of the patches containing the exotic plant. Although $R$. longirostris and $P$. nigricans coexist in vegetation free of exotic plants without apparent mutual aggression, even when they are side by side (MRB per. obs.), the similarity between these species suggests competition, which can happen silently, without obvious aggression (MacArthur 1984).

Benefits were verified for the congeneric $R$. obsoletus following the invasion of a hybrid form of Spartina grass, which increased the survival rate of individuals by offering refuge against predators (Overton et al. 2014). After the introduction of an exotic plant eradication program, the bird population declined (McBroom 2013), as observed in the present study with $R$. longirostris. Conversely, biological invasions of clonal grass Phragmites australis (Cav.) Trin. ex Steud. in Canada have had long-term negative impacts on birds, decreasing species richness and changing community compositions (Robichaud and Rooney 2017).

Officially, Rallus longirostris is not under threat of extinction either globally (BirdLife International 2016) or in Brazil, but it has been deemed threatened as Vulnerable (VU) in that country (Vieira 2015). Regionally, R. longirostris is threatened as Vulnerable in the state of Paraná (Decree \#1.797/2018 of the State of Paraná, November 22, 2018), where the present research was carried out. The fact that $R$. longirostris has benefited from areas dominated by an exotic plant, allowing it to colonize an environment that did not previously occur (Vieira 2015), does not seem to justify interrupting or preventing the management of $U$. arrecta. It is a distinctly aggressive species (Kissman 1997; Thomaz et al. 2009) that reduces the functional diversity of native species due to the presence of allelopathic compounds and its high energy efficiency; resistance to drought periods; and high rates of germination, growth, regrowth, and regeneration (Freitas and Pivello 2005; Bianchini Jr. et al. 2010). The impacts of this grass on native macrophyte (Michelan et al. 2010) and fish (Casatti et al. 2009; Carniatto et al. 2013) communities have been reported, in addition to the impact of habitat suppression for $F$. acutirostris (Reinert et al. 2007) -a species at risk of extinction in Brazil (Ordinance \#444 of the Brazilian Ministério do Meio Ambientes, December 17, 2014).

With the advancing invasion of $U$. arrecta in estuaries, this new nesting niche of $R$. longirostris may increase its population and suggest reversion to the proposed endangered status (Vieira 2015). However, 
invasive plants tend to be ecological traps, attracting species but not sustaining them in the long term (Norbdy et al. 2009; Kloskowski 2012; Stinson and Pejchar 2018). Thus, eventually, increased populations of $R$. longirostris benefitting from $U$. arrecta may undergo future population reduction, even without the management of exotic species. Regardless, the use of subtropical salt marshes and areas dominated by exotic grasses by $R$. longirostris demonstrates unknown ecological plasticity. Long-term monitoring in different estuaries is encouraged because it may reveal other population trends of $R$. longirostris or confirm those presented here, besides allowing a deeper assessment of the impacts of the invasion of $U$. arrecta.

\section{Declarations}

\section{Acknowledgments}

This study was supported by Fundação Grupo Boticário de Proteção à Natureza (FGBPN; projects 0682/20052; 0740/20071; 0908_20112; BL0001_20111,0004_2012, and 1110_20172), Fundo Brasileiro para a Biodiversidade (FUNBIO), and $1^{\text {a }}$ Vara Federal de Paranaguá (process \#50005063420184047008). Most of these projects were developed by Mater Natura-Instituto de Estudos Ambientais, with special financial management support from Helena Zarantonielli. Ricardo Belmonte-Lopes, Daiane D. Sobotka, Cláudia Golec, Leandro Corrêa, Mario Arthur Favretto, Tiago Machado-de-Souza, and Ailton Degues helped with the fieldwork, and the Instituto Água e Terra granted management permissions.

Funding: This study was supported by Fundação Grupo Boticário de Proteção à Natureza (FGBPN; projects 0682/20052; 0740/20071; 0908_20112; BL0001_20111,0004_2012, and 1110_20172), Fundo Brasileiro para a Biodiversidade (FUNBIO), and $1^{\text {a }}$ Vara Federal de Paranaguá (process \#50005063420184047008).

Competing Interests: The authors have no relevant competing interests to disclose.

\section{Author Contributions:}

Conceptualization: Marcos R. Bornschein.

Field procedures: Marcos R. Bornschein, Bianca L. Reinert and Larissa Teixeira.

Funding acquisition: Bianca L. Reinert.

Field administration: Bianca L. Reinert.

Writing: Marcos R. Bornschein, Bianca L. Melchiori, Larissa Teixeira and Giovanna Sandretti-Silva.

Preparing figures and/or tables: Marcos R. Bornschein, Larissa Teixeira.

Data Availability: The raw data in this article is included in the tables and figures. 


\section{References}

1. Bellard C, Cassey P, Blackburn TM (2016) Alien species as a driver of recent extinctions. J R Soc 12(2): 20150623. https://doi.org/10.1098/rsbl.2015.0623

2. Bianchini-Jr I, Cunha-Santino MB, Milan JA, Rodrigues CJ, Dias JHP (2010) Growth of Hydrilla verticillata (L.f.) Royle under controlled conditions. Hydrobiologia 644:301312. https://doi.org/10.1007/s10750-010-0191-1

3. BirdLife International. 2016. Rallus longirostris. The IUCN Red List of Threatened Species 2016: e.T62154828A95190148. Accessed December 27, 2021. https://doi.org/10.2305/IUCN.UK.20163.RLTS.T62154828A95190148.en

4. Bornschein MR (2013) Biologia da conservação do bicudinho-do-brejo Stymphalornis acutirostris (Aves, Thamnophilidae). Dissertation, Universidade Federal do Paraná.

5. Bornschein MR, Pizo MA, Sobotka DD, Belmonte-Lopes R, Golec C, Machado-de-Souza T, Pie MR, Reinert BL (2015) Longevity records and signs of aging in Marsh Antwren Formicivora acutirostris (Thamnophilidae). Wilson j ornithol 127(1):98-102. https://doi.org/10.1676/14-074.1

6. Bornschein MR, Reinert BL, Machado-de-Souza T, Golec C, Whitney BM, Favretto MA (2017) Abundance, occurrence, and seasonality of the Subtropical Doradito (Pseudocolopteryx acutipennis) on the coast of Brazil. Wilson J Ornithol 129(1):199-206. https://doi.org/10.1676/1559-4491129.1.199

7. Carniatto N, Thomaz SM, Cunha ER, Fugi R, Ota R (2013) Effects of an invasive alien poaceae on aquatic macrophytes and fish communities in a Neotropical reservoir. Biotropica 45(6):747-754. https://doi.org/10.1111/btp.12062

8. Casatti L, Ferreira CP, Carvalho FR (2009) Grass-dominated stream sites exhibit low fish species diversity and dominance by guppies: an assessment of two tropical pasture river basins. Hydrobiologia 632:273-283. https://doi.org/10.1007/s10750-009-9849-y

9. Catling PM (2005) Effects of invasive alien plants on birds: some examples from North America. Biodivers 6(3):30-39. https://doi.org/10.1080/14888386.2005.9712772

10. Chesser RT, Banks RC, Cicero C, Dunn JL, Kratter AW, Lovette IJ, Navarro-Sigueza AG, Rasmussen PC, Remsem-Jr JV, Rising JD, Stotz DF, Winker K (2014) Fifty-fifth supplement to the american ornithologists' union check-list of north american birds. Auk 131(4):CSi-CSxv. https://doi.org/10.1642/AUK-14-124.1

11. Cody MS (1985) Habitat selection in birds. Academic Press Inc., Orlando.

12. Cuassolo F, Balseiro E, Modenutti B (2012) Alien vs. native plants in a Patagonian wetland: elemental ratios and ecosystem stoichiometric impacts. Biol Invasions 14:179189. https://doi.org/10.1007/s10530-011-9995-9

13. Doody JP (2001) Coastal conservation and management: an ecological perspective. Kluwer Academic Publishers, Boston.

14. Dunning JB (2008) Handbook of avian body masses, 2nd ed. CRC Press, Boca Raton. 
15. Freitas GK, Pivello V (2005) A ameaça das gramíneas exóticas à biodiversidade. In: Freitas GK, Pivello VR (eds) 0 O cerrado Pé-de-Gigante: ecologia e conservação - Parque Estadual de Vassununga. SMA, São Paulo, pp 234-246.

16. Gedan K, Altieri A, Bertness MD (2011) Uncertain future of New England salt marshes. Mar Ecol Prog Ser 434:229-237. https://doi.org/ 10.3354/meps09084

17. Goodenough A (2010) Are the ecological impacts of alien species misrepresented? A review of the "native good, alien bad" philosophy. Community Ecol 11(1):13-

21. https://doi.org/10.1556/ComEc.11.2010.1.3

18. Greenberg R, Elphick C. Nordby JC, Gjerdrum C, Spautz H, Shriver G, Schmeling B, Olsen B, Marra P, Nur N, Winter M (2006) Flooding and predation: trade-offs in the nesting ecology of tidal-marsh sparrows. Stud in Avian Biol 32:96-109.

19. Hobbs RJ, Higgs E, Harris JA (2009) Novel ecosystems: implications for conservation and restoration. Trends Ecol Evol 34(11):599-605. https://doi.org/10.1016/j.tree.2009.05.012

20. Kissman KG (1997) Plantas infestantes e nocivas, vol. 3. BASF, São Paulo

21. Lee SH, Chang YS (2019) Classification of the global tidal types based on auto-correlation analysis. Ocean Sci 52(2):279-286. https://doi.org/10.1007/s12601-019-0009-7

22. Kloskowski J (2012) Fish stocking creates an ecological trap for an avian predator via effects on prey availability. Oikos 121(10):1567-1576. https://doi.org/10.1111/j.1600-0706.2011.19942.x

23. Levin LA, Neira C, Grosholz ED (2006) Invasive cordgrass modifies wetland trophic function. Ecology 87(2):419-432. https://doi.org/10.1890/04-1752

24. MacArthur RH (2002) Geographical ecology: patterns in the distribution of species. Princeton University Press, Princeton.

25. McBrown J (2013) California Clapper Rail surveys for the San Francisco estuary invasive Spartina Project 2013. State Coastal Conservancy, Oakland.

26. Maley JM, Brumfield RT (2013) Mitochondrial and next-generation sequence data used to infer phylogenetic relationships and species limits in the Clapper/King Rail complex. Condor115(2):316329. https://doi.org/10.1525/cond.2013.110138

27. Marshall RM, Reinert SE (1990) Breeding ecology of seaside sparrows in a Massachusetts salt marsh. Wilson Bull 102:501-513.

28. Meyerson LA, Mooney HA (2007) Invasive alien species in an era of globalization. Front Ecol Environ 5(4):199-208. https://doi.org/10.1890/1540-9295(2007)5[199:IASIAE]2.0.CO;2

29. Michelan TS, Thomaz SM, Mormul RP, Carvalho P (2010) Effects of an exotic invasive macrophyte (tropical signalgrass) on native plant community composition, species richness and functional diversity. Freshw Biol 55:1315-1326. https://doi.org /10.1111/j.1365-2427.2009.02355.x

30. Norbdy JC, Cohen NA, Beissinger SR (2009) Effects of a habitat-altering invader on nesting sparrows: An ecological trap? Biol Invasions 11:565-575. https://doi.org/ 10.1007/s10530-008-9271-9 
31. Overton CT, Casazza ML, Takekawa JY, Strong DR, Holyoak M (2014) Tidal and seasonal effects on survival rates of the endangered California Clapper Rail: does invasive Spartina facilitate greater survival in a dynamic environment? Biol Invasions 16:1897-1914. https://doi.org/10.1007/s10530013-0634-5

32. Reinert BL, Belmonte-Lopes R, Bornschein MR, Sobotka DD, Corrêa L, Pie MR, Pizo MA (2012). Nest and eggs of the Marsh Antwren (Stymphalornis acutirostris): The only marsh-dwelling thamnophilid. Wilson j ornithol 124(2):286-291. https://doi.org/10.1676/11-099.1

33. Reinert BL, Bornschein MR, Firkowski C (2007) Distribuição, tamanho populacional, hábitat e conservação do bicudinho-do-brejo Stymphalornis acutirostris Bornschein, Reinert e Teixeira, 1995 (Thamnophilidae). Rev Bras Ornitol 15:493-519.

34. Reinert SE (2006) Avian nesting response to tidal-marsh flooding: literature review and a case for adaptation in the red-winged blackbird. In: Greenberg R., Maldonado JE, Droege S, McDonald MV (eds). Terrestrial vertebrates of tidal marshes: Evolution, ecology, and conservation. Stud Avian Biol 32:77-95.

35. Robichaud CD, Rooney RC (2017) Long-term effects of a Phragmites australis invasion on birds in a Lake Erie coastal marsh. J Great Lakes Res 43(3):141-149.

https://doi.org/10.1016/j.jglr.2017.03.018

36. Rush AS, Woodrey MS, Cooper RJ (2010) Variation in the nesting habitats of Clapper Rails in tidal marshes of the northern Gulf of Mexico. Condor 112(2):356-362.

https://doi.org/10.1525/cond.2010.090078

37. Schlaepfer MA, Runge MC, Sherman PW (2002) Ecological and evolutionary traps. Trends Ecol Evol 17:474-480. https://doi.org/10.1016/S0169-5347(02)02580-6

38. Shriver WG (2002) Conservation ecology of salt marsh birds in New England. Dissertation, State University of New York.

39. Simberloff D. (2007) Given the stakes, our modus operandi in dealing with invasive species should be "guilty until proven innocent". Conservation Magazine 8:1819.

40. Stinson LT, Pejchar $L$ (2018) The effects of introduced plants on songbird reproductive success. Biol Invasions 20:1403-1416. https://doi.org/10.1007/s10530-017-1633-8

41. Thomaz SM, Carvalho P, Mormul RP, Ferreira FA, Silveira MJ, Michelan TS (2009) Temporal trends and effects of diversity on occurrence of exotic macrophytes in a large reservoir. Acta Ecol 35(5):614-620. https://doi.org/10.1016/j.actao.2009.05.008

42. Veloso HP, Rangel Filho ALR, Lima JC (1991) Classificação da vegetação brasileira, adaptada a um sistema universal. IBGE, Brasil.

43. Vieira BP (2015) Population trends and conservation of the Mangrove Rail. Rev Bras Ornitol 23(3):327-335. https://doi.org/10.1007/BF03544301

44. Vitousek PM, Antonio CMD, Loope, LL, Rejmánek M, Westbrooks R (1997) Introduced species: a significant componente of human-caused global change. NZJ Ecol 21:1-16. 
45. Watson EB, Byrne R (2009) Abundance and diversity of tidal marsh plants along the salinity gradient of the San Francisco Estuary: implications for global change ecology. Plant Ecol 205:113-128. https://doi.org/10.1007/s11258-009-9602-7

46. Zedler JB, Kercher S (2004) Causes and consequences of invasive plants in wetlands: opportunities, opportunists, and outcomes. Crit Rev Plant Sci 23:431-452. https://doi.org/10.1080/07352680490514673

\section{Figures}


A

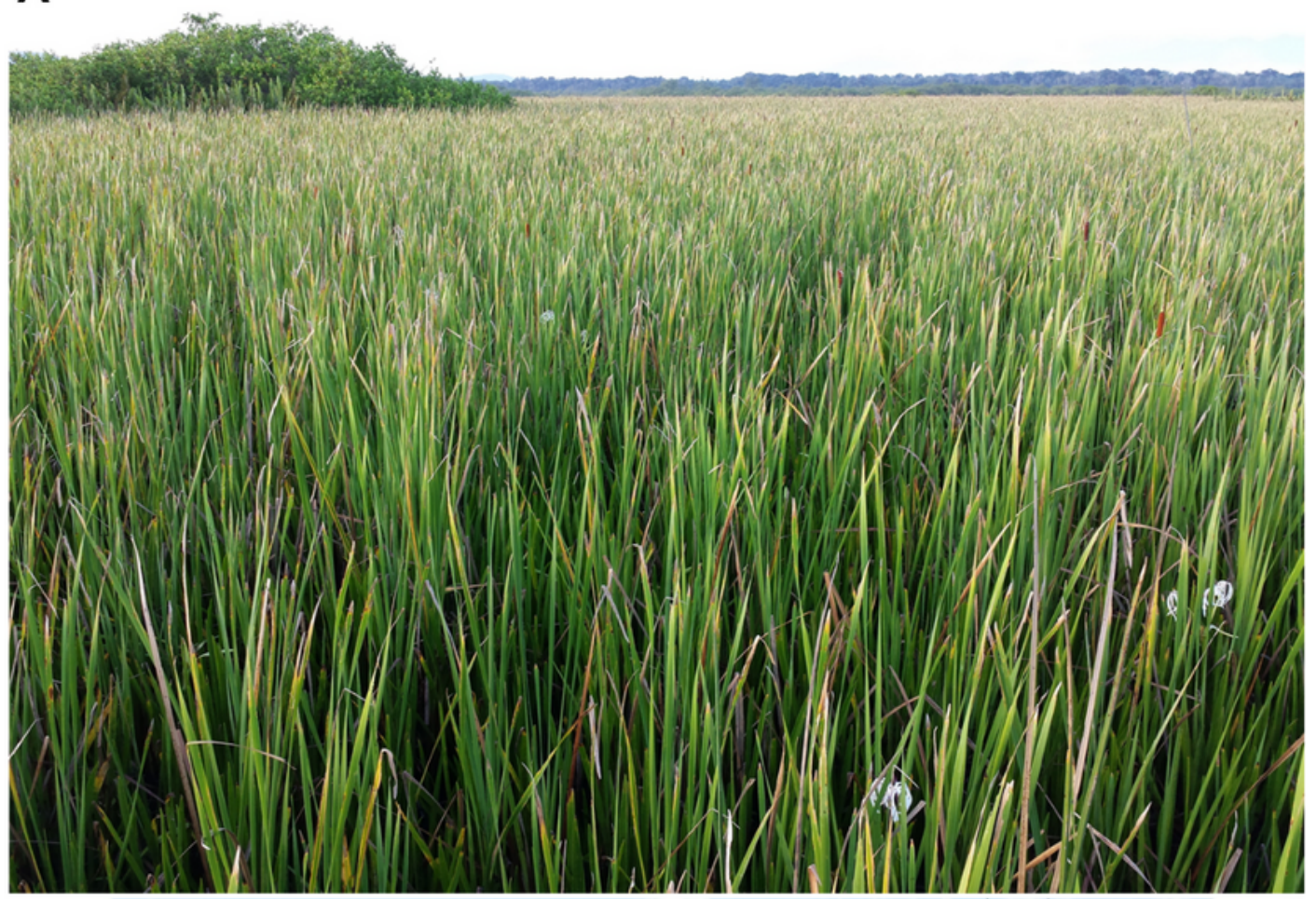

B

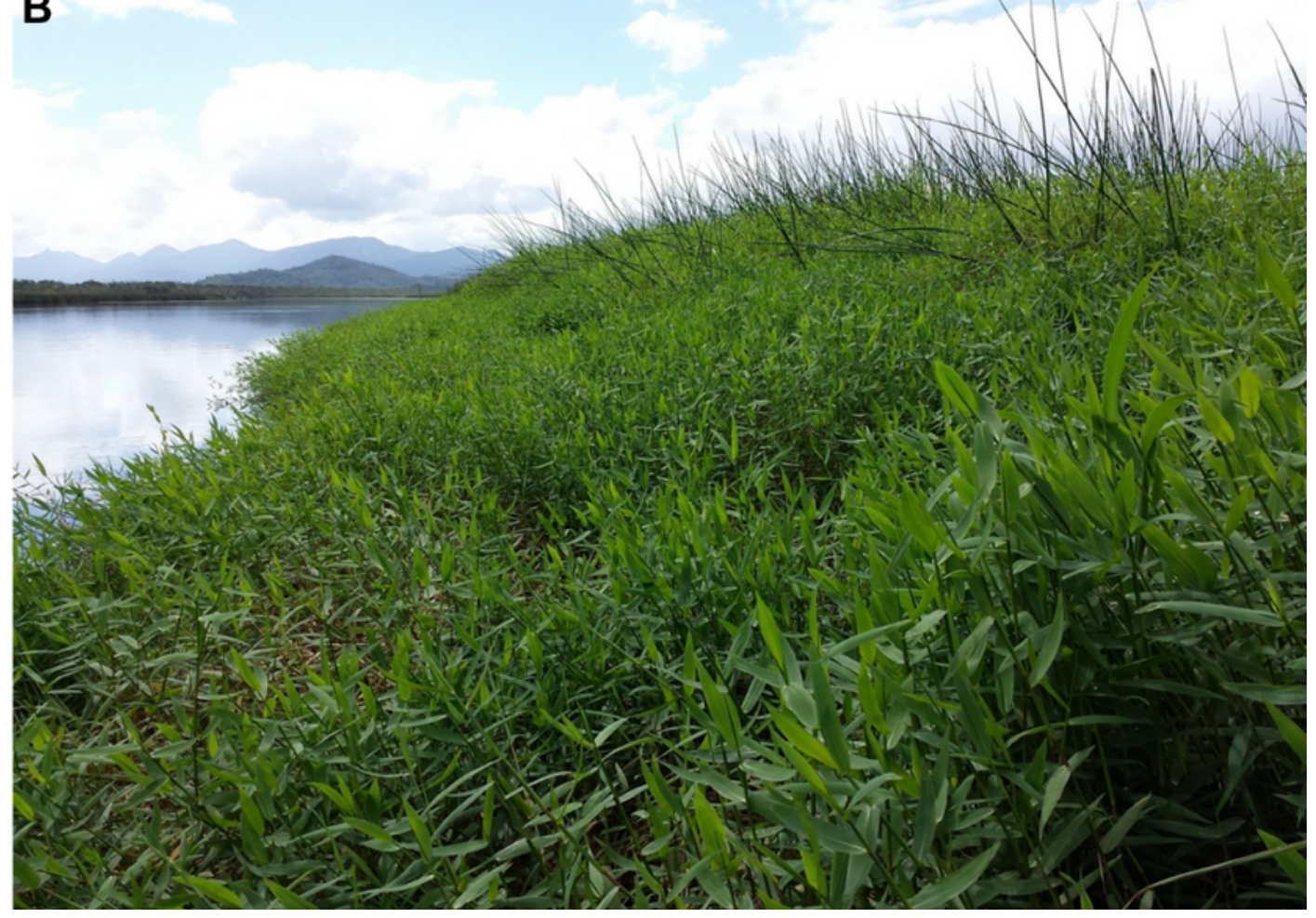

Figure 1

A. Subtropical salt marsh dominated by the crinum lily Crinum americanum $L$. and the southern cattail Typha domingensis Pers., with mangroves of Laguncularia racemosa (L.) C.F. Gaertn in the background of the image, on the left (Folharada Island). B. A subtropical salt marsh invaded by the alien Urochloa arrecta (Hack. ex T. Durand \& Schinz) Morrone \& Zuloaga (Patch 1, Riozinho). Guaratuba Bay, municipality of Guaratuba, Paraná, southern Brazil. Photographs: Marcos R. Bornschein 


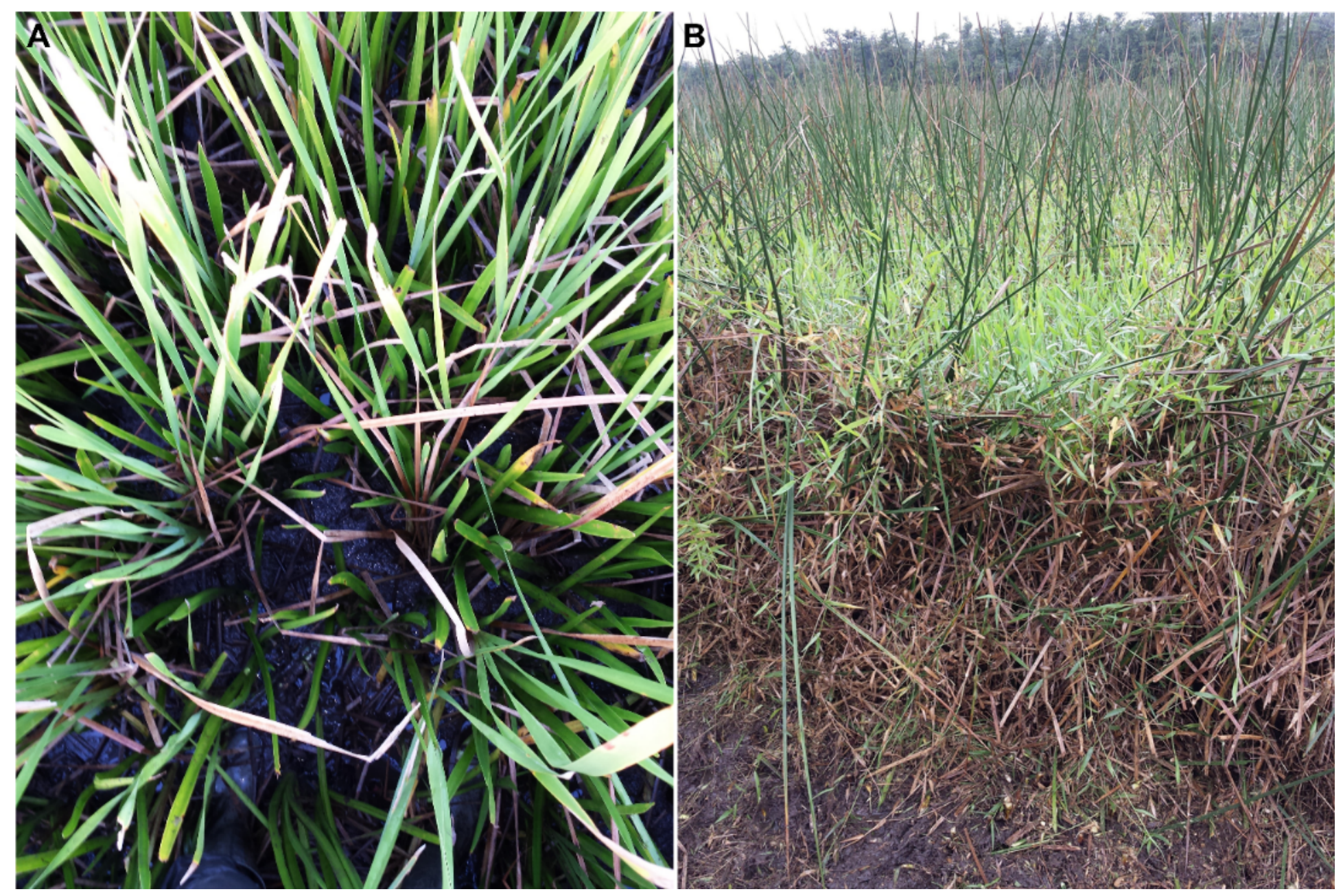

Figure 2

Comparison of the vertical structure of a subtropical salt marsh (A) dominated by the crinum lily Crinum americanum $\mathrm{L}$. and the southern cattail Typha domingensis Pers. with a place dominated by the alien Urochloa arrecta (Hack. ex T. Durand \& Schinz) Morrone \& Zuloaga (Patch 1) and hosting the California bulrush Schoenoplectus californicus (C.A. Mey) Soják (B). In B, the vegetation was partially cut under management intervention. Guaratuba Bay, municipality of Guaratuba, Paraná, southern Brazil. Photographs: Marcos R. Bornschein 


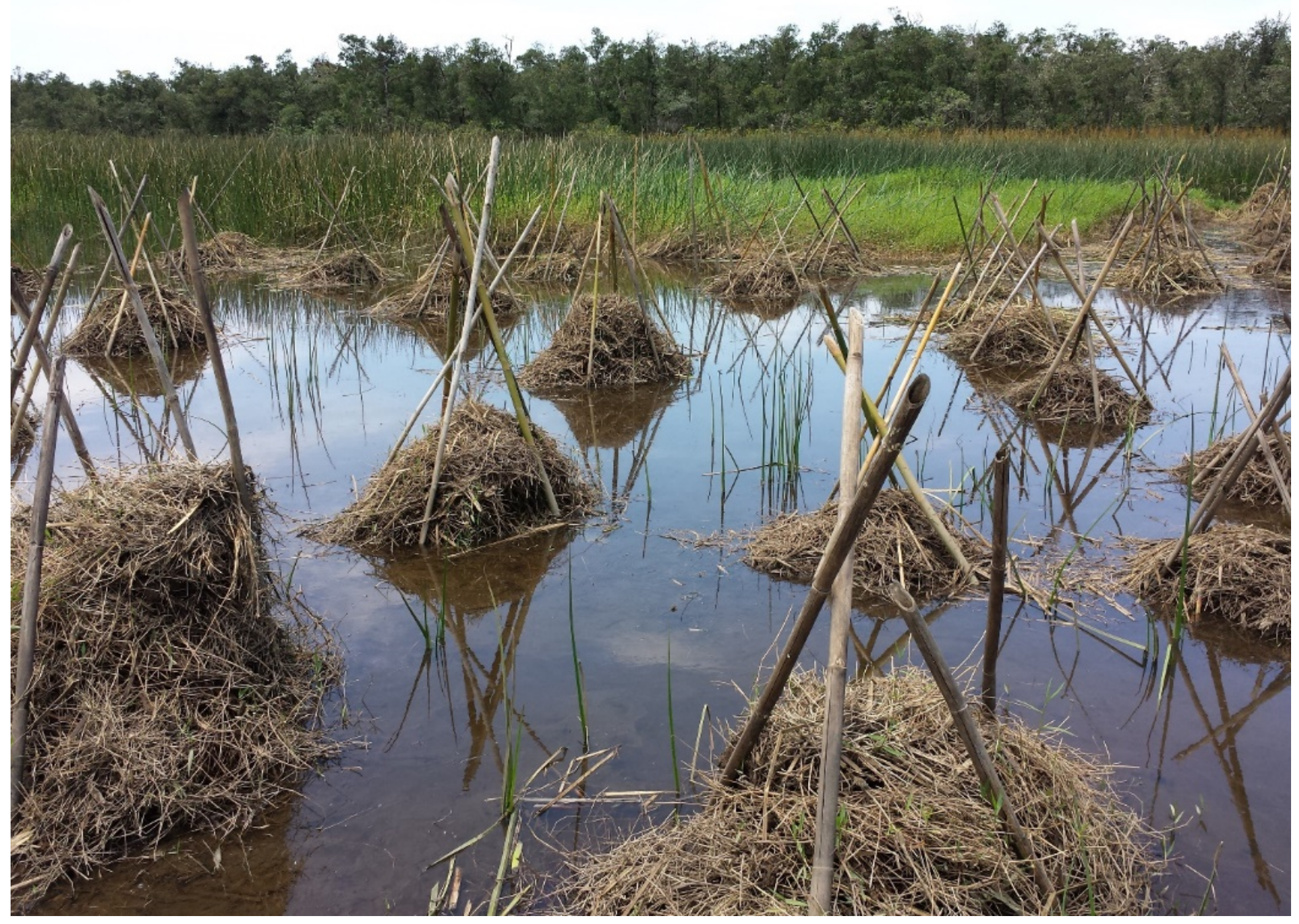

Figure 3

Management of Urochloa arrecta (Hack. ex T. Durand \& Schinz) Morrone \& Zuloaga that invaded the subtropical salt marsh in southern Brazil. Management consisted of clear-cutting the vegetation with brush cutters and piling up the biomass, which was stacked with bamboo supports to prevent it from being carried away by high tides (since the water usually almost reached the tops of the highest piles). The managed area was inspected for the manual removal of sprouts of exotic grass up to six times, and the biomass piles were turned over equally up to six times to ensure the death of sprouts. Photograph: Marcos R. Bornschein 

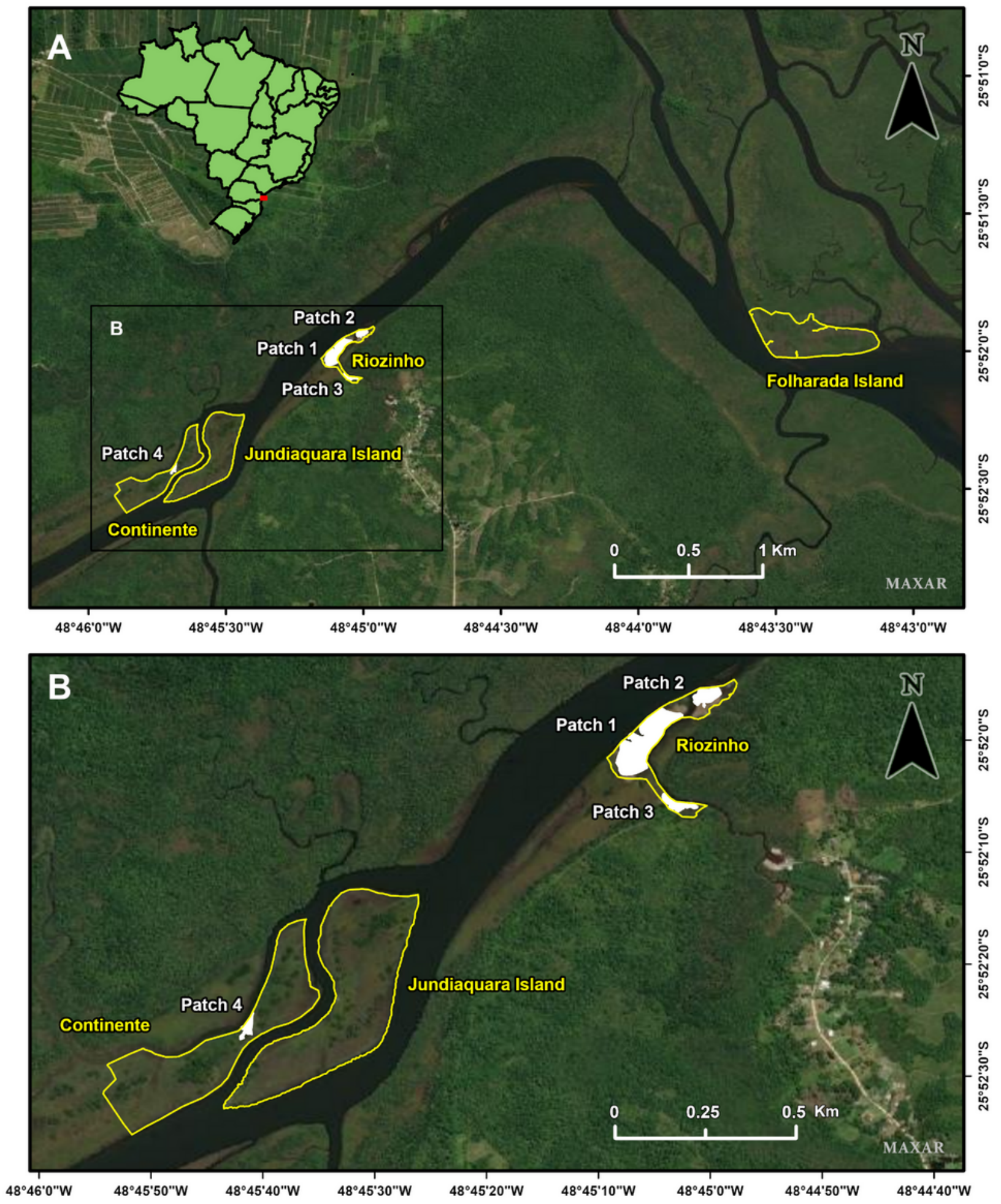

\section{Figure 4}

The area studied from 2006-2022 with occurrence of Rallus longirostris Boddaert, 1783 in Guaratuba Bay, municipality of Guaratuba, Paraná, southern Brazil. We worked in four areas (yellow polygons; A), with four patches dominated by the alien Urochloa arrecta (Hack. ex T. Durand \& Schinz) Morrone \& Zuloaga (at their 2010 size; white polygons; B). Individuals of $R$. longirostris were seen in Patch 1, Patch 2 and Patch 3 (B). Map generated with ArcGIS Pro. Imagery source: MAXAR, IBGE 